\title{
Giant uterine leiomyoma: a case report with literature review
}

\author{
Sonali Kalyan, Sonam Sharma* \\ Department of Pathology, Kalpana Chawla Government Medical College, Karnal, Haryana, India
}

Received: 04 September 2018

Accepted: 05 October 2018

\section{*Correspondence:}

Dr. Sonam Sharma,

E-mail: drsonamsharma@gmail.com

Copyright: $\odot$ the author(s), publisher and licensee Medip Academy. This is an open-access article distributed under the terms of the Creative Commons Attribution Non-Commercial License, which permits unrestricted non-commercial use, distribution, and reproduction in any medium, provided the original work is properly cited.

\begin{abstract}
Uterine leiomyomas are one of the most common entities encountered in routine gynaecological practice; however, the giant uterine myomas are very rare and can often create a diagnostic dilemma and therapeutic challenge owing to their size, non-specific clinical presentation and degenerations. Here, in this article we review the literature on giant uterine leiomyomas and report one such case in a 38-year-old woman who presented with the complaints of vague abdominal lump, enlargement of abdomen, dysmenorrhea, lower abdominal and pelvic pain since last 2 years and a 6month history of increased frequency of micturation. Physical examination and radiological investigations suggested a giant abdominopelvic mass, probably a uterine or an ovarian malignancy. An exploratory laparotomy was performed followed by total hysterectomy. Grossly, the specimen was a $15.2 \mathrm{~kg}$ uterine leiomyoma measuring $18 \times 18 \times 13 \mathrm{~cm}$ in size. Histologically, the benign leiomyoma showed cystic degeneration. The patient's post-operative and follow-up period was uneventful.
\end{abstract}

Keywords: Cystic degeneration, Giant tumor, Leiomyoma, Uterus

\section{INTRODUCTION}

Uterine leiomyomas are the commonest benign tumors of the female genital tract, arising from the smooth muscle cells of the myometrium. ${ }^{1}$ The chances of their occurrence increases during the reproductive period and usually decreases after menopause. ${ }^{2}$ They are found in more than half of the women over the age of 35 years but can also be present in adolescents. ${ }^{3}$ Their exact pathogenesis is still debatable, however hormonal stimulation by estrogen, progesterone and other growth factors plays a pivotal role. Many risk factors have also been implicated for their occurrence like family history, nulliparity, black race, obesity, meat consumption and hypertension. Based on their location they can be categorized as intramural, submucosal and subserosal. Leiomyomas may appear as single or multiple and can be of varying sizes. ${ }^{4}$ Most of the patients have small uterine leiomyoma. However, giant ones do exist and are extremely rare. ${ }^{5}$ They are usually asymptomatic, but large tumors often produce abnormal bleeding, pelvic discomfort (pressure or pain), dysmenorrhea, infertility, frequent urination, constipation, "myomatous erytrocytosis syndrome", Pseudo-Meigs syndrome or preterm labour. ${ }^{6}$ We herein describe an interesting case of giant uterine leiomyoma with degenerative changes along with review of the pertinent world literature so as to create awareness among the dealing clinicians about this enigmatic entity.

\section{CASE REPORT}

A 38-year-old illiterate woman from a rural background presented to gynaecological outpatient department with the complaints of vague abdominal lump, enlargement of abdomen, dysmenorrhea, lower abdominal and pelvic pain since last 2 years and increased frequency of micturation from last 6 months. There was history of recent weight gain and loss of appetite. She had 2 children and her last child birth was 5 years back. Her medical history was non-contributory; she had no major illness or any previous surgical procedures. Her family 
history was not significant. On general examination, her vitals were normal except a protuberant abdomen was seen. On abdominal examination, her abdomen was circumferentially distended by a huge abdominopelvic mass, which was non-tender, firm in consistency and dull on percussion. Per speculum examination revealed normal external genitalia and uterine cervix. On bimanual examination, fornices were full and a very large, firm, mobile, central mass that filled the entire pelvis and abdomen was felt. It was difficult to specify the origin of the mass.

Abdominal ultrasonography confirmed the presence of a huge heterogeneous soft tissue mass arising from the pelvis and occupying almost the entire abdomen, the uterus was poorly visualized. Contrast-enhanced computed tomography (CECT) of the abdomen and pelvis revealed a large solid-cystic mass in the pelvis extending into the abdominal cavity. The mass appeared to be arising from the uterus. The right ovary and fallopian tube were normal, however the left sided adnexa was not visible. The lymphnodes were not enlarged. Her routine hematological, microbiological and other biochemical tests including serum CA 125 (cancer antigen 125) levels and pap smear were within normal limits.

Considering the size of the mass and suspicion of a uterine or an ovarian malignancy, the patient underwent laparotomy. On exploration, bilateral ovaries and fallopian tubes were normal and hence, a total abdominal hysterectomy was performed. The specimen was sent for histopathological examination. On gross examination, a total hysterectomy specimen was received measuring $25 \times 19 \times 15 \mathrm{~cm}$ in size. Cervical length measured $3 \mathrm{~cm}$ and cervical diameter measured $3.5 \mathrm{~cm}$. External surface of the uterus showed few congested blood vessels. On probing, endocervical canal was patent. It weighed 15.2 kg (Figure 1).

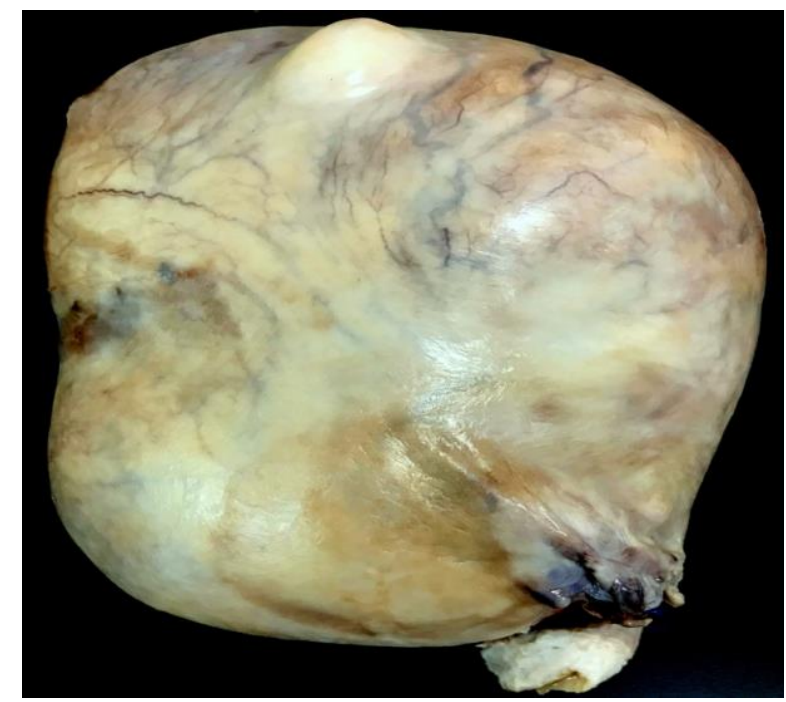

Figure 1: Postoperative specimen of a huge uterus with cervix.
Cut surface showed a large, grayish-white, sharply circumscribed, firm intramural fibroid measuring $18 \times 18 \times 13 \mathrm{~cm}$ in size with characteristic "raw silk" and whorled pattern. Few cystic areas were also evident. No haemorrhage or necrosis was seen. Endometrial canal was compressed, and its thickness measured $0.2-0.3 \mathrm{~cm}$ (Figure 2).

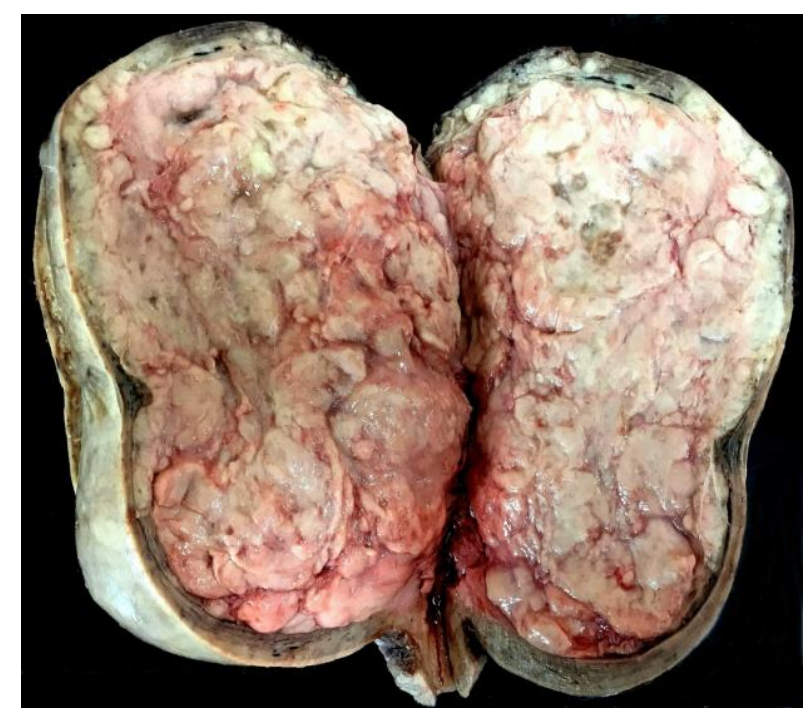

Figure 2: Cut section of the hysterectomy specimen showing multiple gray-white masses with whorled appearance and small cystic areas in between.

Microscopic examination revealed features of a benign leiomyoma with cystic degeneration (Figure 3). The cervix was unremarkable. After the surgical procedure the patient was hospitalized for 10 days and the postoperative period was uneventful. Her symptoms resolved and there were no fresh complaints on 2 month follow-up.

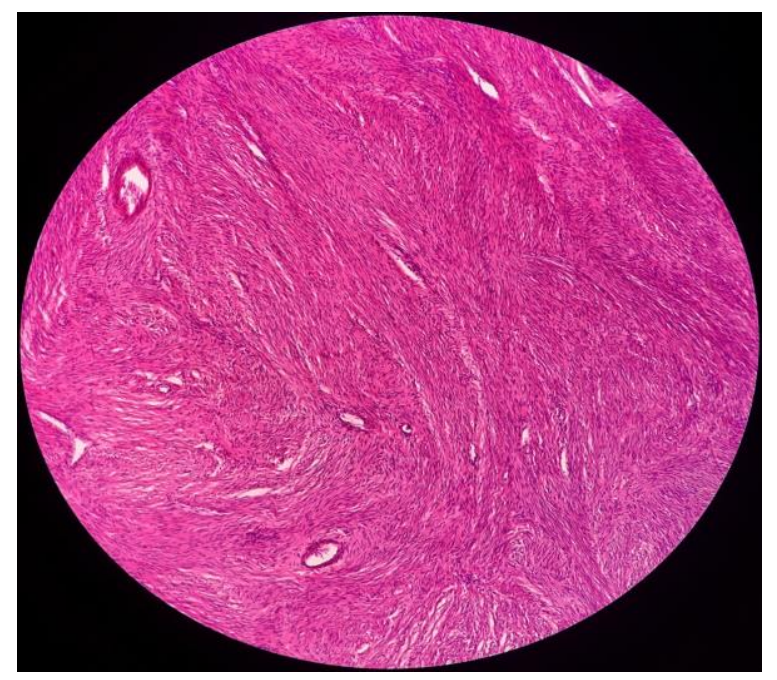

Figure 3: Tumor composed of mixture of spindle shaped smooth muscle fibres and fibrous tissue in varying proportion cut transversely and longitudinally (H and E, x10). 


\section{DISCUSSION}

Giant uterine leiomyomas are uncommon benign neoplasms and are those which weigh more than $11.4 \mathrm{~kg}$ or have a diameter which is more than $17 \mathrm{~cm}$ or dimension $33 \times 28 \times 22 \mathrm{~cm}^{2,7}$ In literature, till date less than 100 cases of giant uterine myomas have been documented worldwide. The largest uterine fibroid ever reported weighed $63.3 \mathrm{~kg}$, which was removed postmortem in 1888 .

Table 1: Giant uterine leiomyoma cases reported in the literature from the year 1800 to 2010.

\begin{tabular}{|c|c|c|c|c|}
\hline $\begin{array}{l}\text { First Author } \\
\text { (Reference) }\end{array}$ & Clinical presentation & $\begin{array}{l}\text { Weight/size of } \\
\text { leiomyoma }\end{array}$ & $\begin{array}{l}\text { Other pathological } \\
\text { features and associated } \\
\text { conditions }\end{array}$ & Outcome \\
\hline Hunter $\mathrm{SH}^{8}$ & $\begin{array}{l}\text { AS and pressure } \\
\text { symptoms }\end{array}$ & $63.6 \mathrm{~kg}$ & NA & Post-mortem \\
\hline Behrend $^{8}$ & AS & $\begin{array}{l}60.7 \mathrm{~kg} \\
60 \times 58 \times 29 \mathrm{~cm}\end{array}$ & $\begin{array}{l}\text { Simulating ovarian cyst } \\
\text { having both solid and } \\
\text { cystic areas }\end{array}$ & $\begin{array}{l}\text { Died of } \\
\text { pneumonia after } \\
48 \text { hours of } \\
\text { operation }\end{array}$ \\
\hline Singhabandhu $\mathrm{B}^{8}$ & NA & $45.4 \mathrm{~kg}$ & NA & Survived \\
\hline Jonas $\mathrm{HS}^{9}$ & NA & $29.48 \mathrm{~kg}$ & NA & NA \\
\hline Evans $\mathrm{AT}^{10}$ & NA & $11.4 \mathrm{~kg}$ & NA & NA \\
\hline Mazzocconi $\mathrm{G}^{11}$ & NA & NA & Pedunculated fundus uteri & Uncomplicated \\
\hline Ozsaran $\mathrm{AA}^{12}$ & $\mathrm{AM}$ and plethora & $14.2 \mathrm{~kg}$ & $\begin{array}{l}\text { Subserous myoma } \\
\text { associated with } \\
\text { erythrocytosis }\end{array}$ & Uneventful \\
\hline Djelmis $\mathbf{J}^{13}$ & NA & $25 \mathrm{~kg}$ & NA & NA \\
\hline Oelsner $\mathrm{G}^{14}$ & $\begin{array}{l}\text { Severe pulmonary } \\
\text { hypertension and } \\
\text { respiratory failure }\end{array}$ & $40 \mathrm{~kg}$ and $43.2 \mathrm{~kg}$ & NA & Uneventful \\
\hline Nguyen-Duc H ${ }^{15}$ & $\begin{array}{l}\text { AM, menorrhagia and } \\
\text { severe anemia }\end{array}$ & NA & $\begin{array}{l}\text { Giant leiomyoma in a } 15- \\
\text { year-old teenager }\end{array}$ & Uneventful \\
\hline Costa $\mathrm{BL}^{16}$ & $\begin{array}{l}\text { AM, constipation and } \\
\text { respiratory difficulty }\end{array}$ & $12.4 \mathrm{~kg}$ & NA & Uneventful \\
\hline Perez $\mathbf{M}^{17}$ & $\mathrm{AD}$ and $\mathrm{WL}$ & $\begin{array}{l}27 \mathrm{~kg} \\
65 \times 54 \times 25 \mathrm{~cm}\end{array}$ & $\begin{array}{l}\text { Uterine myoma with } \\
\text { myxomatous } \\
\text { degeneration, calcification } \\
\text { and chondroid metaplasia }\end{array}$ & Uneventful \\
\hline Panayotidis $\mathrm{C}^{18}$ & $\begin{array}{l}\text { Pelvic mass and } \\
\text { pressure symptoms }\end{array}$ & $\begin{array}{l}4.5 \mathrm{~kg} \\
31 \times 26 \times 15 \mathrm{~cm}\end{array}$ & $\begin{array}{l}\text { Fetal shaped fibroid uterus } \\
\text { (multiple fibroids) }\end{array}$ & Uneventful \\
\hline Nappi $L^{19}$ & $\mathrm{AD}$ & $27.7 \mathrm{~kg}$ & Bilobed giant myoma & Uneventful \\
\hline Karim $T^{20}$ & $\mathrm{AM}$ and $\mathrm{AD}$ & $\begin{array}{l}3.2 \mathrm{~kg} \\
25 \times 15 \times 10 \mathrm{~cm}\end{array}$ & $\begin{array}{l}\text { Giant fibroid in a } 16 \text {-year- } \\
\text { old adolescent girl }\end{array}$ & Uneventful \\
\hline
\end{tabular}

NA: Not Available, AD: Abdominal Distension, AS: Abdominal swelling, AM: Abdominal mass, AE: Abdominal enlargement, WL: Weight loss

On the other hand, the largest one ever removed from a patient who survived the procedure weighed $45.4 \mathrm{~kg}$. This fibroid was reportedly the 34th weighing more than $18.2 \mathrm{~kg}$ since $1878 .^{8}$

Table 1 summarizes the clinicopathological features of giant uterine leiomyomas which were reported from the year 1800 till 2010. On further extensive reviewing the cases since the year 2011 till date (Table 2 and 3) it was noted that there was a surge in the number of patients being reported with giant uterine leiomyomas.

The uterine fibroids have an unremarkable potential to grow to an incredible extreme size before disabling the patient or producing appreciable symptoms. The only limit on size seems to be the capability of the host to bear it. This is owing to the relatively large volume of the abdominal cavity, the distensibility of the anterior abdominal wall, and the slow growth rate of this tumor. 
Table 2: Literature review of giant uterine leiomyoma cases reported from the year 2011 to 2014.

\begin{tabular}{|c|c|c|c|c|}
\hline $\begin{array}{l}\text { First Author } \\
\text { (Reference) }\end{array}$ & Clinical presentation & $\begin{array}{l}\text { Weight/size of } \\
\text { leiomyoma }\end{array}$ & $\begin{array}{l}\text { Other pathological } \\
\text { features and associated } \\
\text { conditions }\end{array}$ & Outcome \\
\hline Steward $\mathrm{RG}^{21}$ & $\begin{array}{l}\text { AE with history of uterine } \\
\text { fibroids }\end{array}$ & $\begin{array}{l}11.618 \mathrm{~kg} \\
31 \times 26 \times 14 \mathrm{~cm} \\
\text { (largest) }\end{array}$ & $\begin{array}{l}\text { Conglomerate, } \\
\text { pedunculated leiomyomata }\end{array}$ & Uneventful \\
\hline Savulescu $\mathrm{F}^{6}$ & $\begin{array}{l}\text { AE, WG, pressure symptoms, } \\
\text { dysmenorrhea, dyspareunia, } \\
\text { menorrhagia, lower abdominal } \\
\text { and pelvic pain, frequent } \\
\text { urination and constipation }\end{array}$ & $\begin{array}{l}18.1 \mathrm{~kg} \\
33 \times 28 \times 22 \mathrm{~cm}\end{array}$ & $\begin{array}{l}\text { Bilobed solid tumor with } \\
\text { multiple subserosal fibroids }\end{array}$ & Uneventful \\
\hline Murtaza B 22 & $\begin{array}{l}\text { AM, dull pain in lumbar region, } \\
\text { constipation, WL }\end{array}$ & $\begin{array}{l}7.4 \mathrm{~kg} \\
55 \times 40 \times 35 \mathrm{~cm}\end{array}$ & $\begin{array}{l}\text { Pedunculated subserosal } \\
\text { fibroid with bilateral } \\
\text { hydronephrosis }\end{array}$ & $\begin{array}{l}\text { Uneventful with } \\
\text { complete } \\
\text { regression of } \\
\text { bilateral } \\
\text { hydronephrosis } \\
\text { after } 2 \text { months of } \\
\text { surgery. }\end{array}$ \\
\hline Öndeş B ${ }^{23}$ & $\mathrm{AD}$ & $\begin{array}{l}25 \mathrm{~kg} \\
33 \times 28 \times 23 \mathrm{~cm}\end{array}$ & $\begin{array}{l}\text { Few cystic and ulcerated } \\
\text { areas }\end{array}$ & $\begin{array}{l}\text { Postoperative } \\
\text { wound dehiscence }\end{array}$ \\
\hline $\begin{array}{l}\text { Al-Obaidi } \\
\mathrm{SM}^{24}\end{array}$ & $\begin{array}{l}\text { AM, AD, constipation, } \\
\text { difficulty in initiation of } \\
\text { micturition }\end{array}$ & $\begin{array}{l}19.8 \mathrm{~kg} \\
60 \times 45 \times 25 \mathrm{~cm}\end{array}$ & $\begin{array}{l}\text { Atrophied uterus with } \\
\text { fibroid and cystic } \\
\text { degeneration of benign } \\
\text { ovarian tissue }\end{array}$ & Uneventful \\
\hline Alam IP ${ }^{2}$ & $\begin{array}{l}\mathrm{AM}, \mathrm{AD}, \text { occasional } \\
\text { constipation, increased } \\
\text { frequency of micturition }\end{array}$ & $9.5 \mathrm{~kg}$ & $\begin{array}{l}\text { Multiple fibroids, few } \\
\text { showing necrosis and few } \\
\text { others showing cystic and } \\
\text { degenerative changes }\end{array}$ & Uneventful \\
\hline Aydin $C^{25}$ & $\begin{array}{l}\text { Lower abdominal pain, } \mathrm{AD} \text {, } \\
\text { recent } \mathrm{WG} \text { of } 25 \mathrm{~kg}\end{array}$ & $33 \times 20 \times 18 \mathrm{~cm}$ & $\begin{array}{l}\text { Multiloculated, cystic, } \\
\text { pedunculated leiomyoma } \\
\text { with extensive cystic } \\
\text { degeneration }\end{array}$ & Uneventful \\
\hline Mate $S^{26}$ & $\begin{array}{l}\text { Acute dyspnea and severe acute } \\
\text { anemia (due to intratumoral } \\
\text { bleeding) }\end{array}$ & $13.5 \mathrm{~kg}$ & Pedunculated leiomyoma & Uneventful \\
\hline $\begin{array}{l}\text { Gajewska } \\
\mathrm{M}^{27}\end{array}$ & $\mathrm{AE}$ & $\begin{array}{l}25 \mathrm{~cm} \text { in } \\
\text { diameter }\end{array}$ & $\begin{array}{l}\text { Pedunculated leiomyoma } \\
\text { with cystic degeneration }\end{array}$ & Uneventful \\
\hline Funaki K ${ }^{28}$ & $\mathrm{AD}$ and $\mathrm{WG}$ & $\begin{array}{l}8 \mathrm{~kg} \\
40 \times 40 \times 30 \mathrm{~cm}\end{array}$ & $\begin{array}{l}\text { Subserous leiomyoma with } \\
\text { cystic degeneration }\end{array}$ & Uneventful \\
\hline $\begin{array}{l}\text { Konard } \\
\text { Wronski }^{1}\end{array}$ & $\begin{array}{l}\text { Abdominal pain, } \mathrm{AD}, \\
\text { constipation }\end{array}$ & $24.2 \times 17.3 \mathrm{~cm}$ & $\begin{array}{l}\text { Uterine leiomyomata with } \\
\text { cystic degeneration }\end{array}$ & Uncomplicated \\
\hline Ezugwu EC ${ }^{4}$ & AS, infertility, WL & $\begin{array}{l}16.8 \mathrm{~kg} \text { (total } \\
\text { fibroid weight) } \\
\text { Largest: } 12.4 \\
\mathrm{~kg}, 32 \times 24 \mathrm{~cm}\end{array}$ & $\begin{array}{l}\text { Large conglomerate fibroid } \\
\text { masses attached to fundus } \\
\text { along with multiple } \\
\text { intramural fibroid } \\
\text { seedlings. }\end{array}$ & $\begin{array}{l}\text { Uneventful } \\
\text { recovery and } \\
\text { successful } \\
\text { pregnancy seven } \\
\text { months following } \\
\text { myomectomy. }\end{array}$ \\
\hline Moris $\mathrm{D}^{7}$ & $\begin{array}{l}\text { Progressive constipation, } \\
\text { increasing abdominal size, back } \\
\text { pain, vague abdominal pressure } \\
\text { sensations and urinary } \\
\text { frequency }\end{array}$ & $\begin{array}{l}28.1 \mathrm{~kg} \\
62 \times 39 \times 21 \mathrm{~cm}\end{array}$ & Solid and nodular & Uneventful \\
\hline
\end{tabular}


As a result, these patients can present in a physical condition which is unlike that of a typical woman with fibroids, but instead more like that of a much older patient with multiple comorbidities. ${ }^{21}$ However, the giant neoplasms frequently causes abnormal periods, pelvic pain and pressure effects on lungs, urinary bladder, ureters and other adjacent organs leading to further complications like lower-limb thrombosis as well as renal and respiratory failure. ${ }^{2}$

Table 3: Giant uterine leiomyoma cases reported from the year 2015 to 2018 (till date).

\begin{tabular}{|c|c|c|c|c|}
\hline $\begin{array}{l}\text { First Author } \\
\text { (Reference) }\end{array}$ & Clinical presentation & $\begin{array}{l}\text { Weight/size of } \\
\text { leiomyoma }\end{array}$ & $\begin{array}{l}\text { Other pathological } \\
\text { features and associated } \\
\text { conditions }\end{array}$ & Outcome \\
\hline Kalayci $\mathrm{TO}^{29}$ & Abdominal pain and AD & $30 \times 25 \times 17 \mathrm{~cm}$ & $\begin{array}{l}\text { Pedunculated subserosal } \\
\text { leiomyoma with degenerative } \\
\text { changes }\end{array}$ & Uneventful \\
\hline Yavuz $\mathrm{A}^{30}$ & Menometrorrhagia and AS & $9.8 \mathrm{~kg}$ & Associated umbilical hernia & Uneventful \\
\hline Mulayim B ${ }^{31}$ & No symptoms or complaints & $\begin{array}{l}3.98 \mathrm{~kg} \\
17 \mathrm{~cm}\end{array}$ & $\begin{array}{l}\text { Intramural, cellular leiomyoma } \\
\text { without secondary changes }\end{array}$ & Uneventful \\
\hline Sharma $\mathrm{RP}^{32}$ & $\begin{array}{l}\text { Gradual WG, increasing } \\
\text { abdominal size, vague abdominal } \\
\text { pressure sensations, } \\
\text { dysmenorrhoea, dyspareunia, } \\
\text { menorrhagia, lower abdomen and } \\
\text { pelvic pain, frequent urination } \\
\text { and constipation }\end{array}$ & $\begin{array}{l}20 \mathrm{~kg} \\
36.4 \times 28.7 \times 23.3 \\
\mathrm{~cm}\end{array}$ & $\begin{array}{l}\text { Fibroid arising from fundus } \\
\text { region }\end{array}$ & Uneventful \\
\hline Reshmy JR ${ }^{33}$ & $\mathrm{AD}$ and lower abdominal pain & $28 \times 20 \times 10 \mathrm{~cm}$ & $\begin{array}{l}\text { Leiomyoma with cystic } \\
\text { degeneration }\end{array}$ & NA \\
\hline Rahman $\mathrm{H}^{5}$ & $\begin{array}{l}\text { AS, vague abdominal discomfort, } \\
\text { lower abdomen and pelvic pain } \\
\text { and frequency of urination }\end{array}$ & $\begin{array}{l}11.6 \mathrm{~kg} \\
43 \times 32 \times 23 \mathrm{~cm}\end{array}$ & Associated erythrocytosis & $\begin{array}{l}\text { Complete } \\
\text { recovery after } \\
\text { hysterectomy }\end{array}$ \\
\hline Carbunaru $\mathrm{A}^{34}$ & AM with left lower limb swelling & $\begin{array}{l}4.5 \mathrm{~kg} \\
25 \times 21 \times 20 \mathrm{~cm}\end{array}$ & $\begin{array}{l}\text { Myoma with hyaline } \\
\text { degeneration and associated } \\
\text { deep vein thrombosis of left } \\
\text { lower limb }\end{array}$ & Uneventful \\
\hline $\begin{array}{l}\text { Gennaro } \\
\text { Della Rossa } \\
\text { MN }^{35}\end{array}$ & $\mathrm{AM}$ & $23 \times 19 \times 12 \mathrm{~cm}$ & $\begin{array}{l}\text { Intramural fibroid with } \\
\text { minimal nuclear atypia and } \\
\text { low mitotic activity with } \\
\text { interstitial edematous } \\
\text { degeneration without signs of } \\
\text { necrosis }\end{array}$ & $\begin{array}{l}\text { Uterine } \\
\text { reconstruction } \\
\text { following } \\
\text { myomectomy } \\
\text { with } \\
\text { uneventful } \\
\text { recovery }\end{array}$ \\
\hline Ramteke $S^{36}$ & $\begin{array}{l}\mathrm{AD}, \mathrm{WL} \text {, decreased appetite, } \\
\text { bleeding per vaginum }\end{array}$ & $\begin{array}{l}6.5 \mathrm{~kg} \\
26 \times 23 \times 18 \mathrm{~cm}\end{array}$ & Intramural fibroid & NA \\
\hline Muller $\mathrm{R}^{37}$ & $\mathrm{AE}$ and $\mathrm{WL}$ & $15.6 \mathrm{~kg}$ & NA & Uneventful \\
\hline Hrgovic $Z^{38}$ & $\mathrm{AD}$ & $25 \mathrm{~cm}$ diameter & $\begin{array}{l}\text { Myoma } \\
\text { spontaneously regressed in } \\
\text { size } 3 \text { years after delivery }\end{array}$ & $\begin{array}{l}\text { Pregnancy } \\
\text { outcome } \\
\text { favourable }\end{array}$ \\
\hline Bartos $V^{39}$ & $\mathrm{AE}$ & $\begin{array}{l}8.1 \mathrm{~kg} \\
30 \times 30 \times 20 \mathrm{~cm}\end{array}$ & $\begin{array}{l}\text { Subserous leiomyoma with } \\
\text { regressive and degenerative } \\
\text { changes }\end{array}$ & Uneventful \\
\hline
\end{tabular}

NA: Not available, AD: Abdominal distension, AS: Abdominal swelling, AM: Abdominal mass,

AE: Abdominal enlargement, WL: Weight loss, WG: Weight gain.

Furthermore, on enlargement, uterine fibroids undergo different types of degeneration such as hyaline, cystic, myxoid or red degeneration and dystrophic calcification. Hyaline degeneration is most common $(60 \%$ cases of leiomyomas) while cystic degeneration occurs in $4 \%$ of such cases. ${ }^{1}$ These degenerations arise due to the inadequate blood supply and seem to depend on the degree and rapidity of the onset of vascular insufficiency. However, researchers have found no relationship between any symptoms and the incidence of degenerative 
changes. $^{2}$ The diagnostic approach whenever a uterine leiomyoma is suspected is the pelvic examination which is the first step of evaluation in such patients, however, usually the smaller ones are not palpated and it is only the very large myomas which can be felt during examination. ${ }^{4}$ Therefore, imaging studies should be considered as they are helpful in determining the location, number, size and extent of the leiomyomas. ${ }^{21}$

Ultrasonography is preferred as the initial screening tool because it is least invasive and most cost-effective investigation. $^{2,6}$ Computed Tomography (CT) and Magnetic Resonant Imaging (MRI) are quite helpful especially for ruling out any malignant transformation and in differential diagnosis but they have certain limitations. On CT scans, sometimes the leiomyomas are indistinguishable from healthy myometrium unless they are calcified or necrotic while MRI has limited availability and high cost restricting its use. ${ }^{6}$ Tumor markers have also been implicated to play an important role in its diagnosis as based on them the likelihood of malignancy can be ruled out. However, there is no single best modality to diagnose it pre-operatively and usually the giant uterine leiomyomas are diagnosed after laparotomy on histopathological examination. The differential diagnosis includes adenomyosis, hematometra, uterine cancer (carcinoma, sarcoma and carcinosarcoma), ovarian and retroperitoneal cysts or malignancy. ${ }^{21,25,27}$ In the present case study too, it was confused with a uterine or an ovarian malignancy both clinically and radiologically. However, it turned out to be a case of giant uterine leiomyoma with cystic degeneration on histopathology.

The treatment in cases of giant uterine leiomyomas is usually individualized as both the symptoms severity and patients desire to preserve the fertility are very important factors in determining any therapeutic intervention. ${ }^{6}$ The options include expectant management, medical management, surgery, interventional procedures like uterine artery embolization and ablative techniques. Expectant management with observation is done in cases of women with asymptomatic small and large fibroids, since rarely uterine leiomyomas may undergo sarcomatous transformation. Patients with giant myomas present as unusual challenge even for the most experienced gynecologists mainly due to massive blood loss caused by increased vascularity and postoperative possible complications like injury to bowel and urinary tract, infections, haematomas. ${ }^{3}$ Therefore, the medical management using Gonadotrophin Releasing Hormone (GnRH) analogues has been used to suppress estrogen production, thereby reducing the size of existing myomas and blood loss before the surgery. Uterine artery embolization also aims to decrease intraoperative blood loss, as it causes myoma infarction with very less adverse effects. Surgical treatment includes hysterectomy, myomectomy and myolysis. The removal of giant uterine leiomyomas by total abdominal hysterectomy with or without salpingo-oophorectomy is the traditional treatment of choice as these leiomyomas may cause infertility and in the presence of pregnancy they may affect the outcome. However, other approaches like vaginal and laparoscopic hysterectomies are associated with less postoperative complications and quicker recovery of the patient as compared to laparotomy /abdominal approach. Myomectomy is performed through laparotomy, laparoscopy or hysteroscopy and is preferred in symptomatic women who refuse hysterectomy or have a desire to retain their fertility. However, it causes significant perioperative morbidity. Myolysis including mono or bipolar cautery, Nd-YAG laser vaporisation or cryotherapy is currently experimental and is associated with risk of recurrence. ${ }^{2}$

\section{CONCLUSION}

Giant uterine leiomyomas are exceedingly rare and can present with variable clinical manifestations. Therefore, this entity should always be kept in mind while dealing with patients with giant abdominopelvic tumors. Ultrasound stays as the initial screening tool for its diagnosis, but most of them are usually diagnosed on laparotomy followed by histopathological examination. Nevertheless, the treatment approach for every patient should be individualized and appropriate multidisciplinary approach with meticulous patient pre and postoperative care is essential for a better outcome in such patients.

\section{Funding: No funding sources \\ Conflict of interest: None declared \\ Ethical approval: Not Required}

\section{REFERENCES}

1. Wronski K. Giant uterine leiomyoma: case report and review of literature. New Med. 2014;3:89-91.

2. Alam IP, Newaz R. A Case of Giant Fibroid Uterus. Bangladesh J Obstet Gynaecol. 2012;27(1):27-30.

3. Cramer SF, Patel A. The frequency of uterine leiomyomas. Am J Clin Pathol. 1990;94(4):435-8.

4. Ezugwu EC, Iyoke CA, Ezugwu FO, Ugwu G. Successful Pregnancy Following Myomectomy for Giant Uterine Fibroid in an Infertile Woman. J Reprod Infertil. 2014;15(4):233-6.

5. Rahman H, Sharma BK, Khalda E, Pathak R, Dubey S. Giant leiomyoma uterus with myomatous erythrocytosis syndrome: A rare case report. J Cases Obstet Gynecol. 2016;3(3):88-91.

6. Savulescu F, Iordache I, Albiţa O, Hristea R, Dumitru C, Iordache A, et al. Giant uterine leiomyoma.Chirurgia (Bucur). 2011;106(5):665-8.

7. Moris D, Vernadakis S. Giant uterine leiomyoma mimicking pregnancy. Mayo clinic proceedings. 2014;89(6):53-4.

8. Powell JL. Giant fibroids. J Am Coll Surg. 2004;199(4):670. 
9. Jonas HS, Masterson BJ. Giant uterine tumors: case report and review of the literature. Obstet Gynecol. 1977;50 (1 Suppl):2s-4.

10. Evans AT 3rd, Pratt JH. A giant fibroid uterus. Obstet Gynecol. 1979;54(3):385-6.

11. Mazzocconi G, Stasio A, Campli M, Sbaffi E, Voccia E. Giant pedunculated leiomyoma of the fundus uteri. G Chir. 1996;17(8-9):413-5.

12. Ozsaran AA, Itil IM, Terek C, Kazandi M, Dikmen Y. Giant myoma and erythrocytosis syndrome. Aust NZJ Obstet Gynaecol. 1999;39(3):384-6.

13. Djelmis J, Mayer D, Majerovic M, Radanovic B, Starcevic V. Giant uterine leiomyoma devascularized by embolization prior to surgical removal. Eur J Obstet Gynecol Reprod Biol. 2001;99(2):278-80.

14. Oelsner G, Elizur SE, Frenkel Y, Carp H. Giant uterine tumors: two cases with different clinical presentations. Obstet Gynecol. 2003;101(5 Pt 2):1088-91.

15. Nguyen-Duc H. Large uterine fibroma in a 15 year old adolescent. Giant leiomyoma in adolescence. J Gynecol Obstet Biol Reprod (Paris). 2003;32(8 Pt 1):748-50.

16. Costa Benavente L, Silva Barroso F, Avila Flores E. Giant uterine myoma. Ginecol Obstet Mex. 2005;73(10):563-5.

17. Perez M, Ramon JM. Large abdominal mass due to a giant uterine leiomyoma. Mayo Clin Proc. 2006;81(11):1415.

18. Panayotidis C, Salleh S, Martin J E, Hirsh P, Wynn J. Giant uterine leiomyomas: dilemmas in surgical management. Gynaecol Surg. 2006;3(1):37-40.

19. Nappi L, Matteo M, Giardina S, Rosenberg P, Indraccolo U, Greco P. Management of uterine giant myoma. Arch Gynecol Obstet. 2008;278(1):61-3.

20. Karim T, Patil K, Panchal A. A case of giant fibroid uterus in an adolescent girl of 16 . NJOG. 2010;4(2):49-50.

21. Steward RG, Denhartog HW, Katz AR. Giant uterine leiomyomata. Fertility Steril. 2011;95(3):1121.e15-7.

22. Murtaza B, Ahmad M, Afzal M, Khan NA, Saeed S. Pedunculated uterine fibroid with hydronephrosis and colonic adhesions. PAFMJ. 2011;61(1):82-5.

23. Öndeş B, Yumru AE, Dinçgez B. Giant Uterine Leiomyoma. JAREM. 2011;1:32-32.

24. Al-Obaidi SM, Akool MA. A case of Giant Uterine Fibroid in a Young Woman. Iraqi Postgraduate Med J. 2012;11(4):588-92.

25. Aydin C, Eris S, Yalcin Y, Sen Selim H. A giant cystic leiomyoma mimicking an ovarian malignancy. Int J Surg Case Rep. 2013;4(11):1010-2.

26. Mate S, Szatmari E, Sipos M, Szell J, Szantho A, Rigo J Jr. Giant uterine leiomyoma causing acute symptoms. Orv Hetil. 2013;154(10):387-90.
27. Gajewska M, Kosińska-Kaczyńska K, Marczewska J, Kamiński P. Huge uterine leiomyoma with degenerative changes mimicking ovarian carcinomaa case report. Ginekol Pol. 2013;84(2):147-50.

28. Funaki K, Fukunishi H, Tsuji Y, Maeda T, Takahashi T. Giant cystic leiomyoma of the uterus occupying the retroperitoneal space. J Radio Case Rep. 2013;7(12):35-40.

29. Kalayci TO, Akath AN, Sonmezgoz F, Samdanci ET. A giant subserosal uterine leiomyoma mimicking an abdominal mass: multimodal imaging data. Acta Medica Iranica. 2015;53(4):246-9.

30. Yavuz A, Astepe B, Terzi H, Kale A. Management of uterine giant myoma: case report. Sakaryamj. 2015;5(1):34-8.

31. Mulayim B. Unaware of a large leiomyoma: A case report with respect to unusual symptoms of large leiomyomas. Ann Med Surg (Lond). 2015;4(4):4313 .

32. Sharma RP, Sharma N, Sharma K, Sharma A, Jain A, Prasad A. Giant Uterine Leiomyoma and Review of Literature. IJMSCI. 2015;2(1):640-4.

33. Reshmy JR, Misra B, Rai R. Giant cystic leiomyoma masquerading as ovarian tumour- a case report. Sch J Med Case Rep. 2015;3(7):608-10.

34. Carbunaru A, Herlea, Ionescu M, Dumitrascu T. Extensive Left Iliac Veins and Inferior Vena Cava Thrombosis Revealing a Giant Uterine Myoma. Rom J Intern Med. 2016;54(1):70-3.

35. Gennaro Della Rossa MN, Santana BN, VerdejoArias MR, Cardenas EV, Arranz JP. Uterine Reconstruction Due to a Giant Myoma. A Case Report and Literature Review. OJOG. 2016;6:64-72.

36. Ramteke S, Joshi P, Zararia A, Dharmale D. Fast Growing Giant Intamural Leiomyoma: a Case Report. Int J Health Sci Res. 2016;6(4):542-5.

37. Muller R, Bresky P. Giant uterine fibroid- case report. Ceska Gynekol. 2016;81(1):71-5.

38. Hrgovic Z, Habek D, Cerkez Habek J, Hrgovic I, Jerkovic Gulin S, Gulin D. Spontaneous pregnancy during ulipristal acetate treatment of giant uterine leiomyoma. J Clin Pharm Ther. 2018;43(1):121-23.

39. Bartos V, Korec P, Ficek R. Giant Uterine Leiomyoma in a Young Woman as an Incidental Finding After a Car Accident: a Case Report. Acta Medica (Hradec Kralove). 2018;61(1):29-32.

Cite this article as: Kalyan S, Sharma S. Giant uterine leiomyoma: a case report with literature review. Int J Reprod Contracept Obstet Gynecol 2018;7:4779-85. 